\title{
Re-imagining Holocaust: A Reading of John Boyne's The Boy in the Striped Pyjamas
}

\author{
Sharon Soby Varghese ${ }^{1}$, Bibin John Babujee ${ }^{2}$
}

${ }^{1}$ NSS Training College, Changanacherry, Kerala, India

${ }^{2} \mathrm{St}$ Berchmans College, Changanacherry, Kerala, India

Received: 10 Oct 2021; Received in revised form: 18 Nov 2021; Accepted: 22 Nov 2021; Available online: 27 Nov 2021

(C)2021 The Author(s). Published by Infogain Publication. This is an open access article under the CC BY license

(https://creativecommons.org/licenses/by/4.0/).

\begin{abstract}
The paper entitled "Re-imagining Holocaust: A Reading of John Boyne's The Boy in the Striped Pyjamas" deals with the various dimensions of Holocaust literature. The article begins with a chapter that explores the various features of Holocaust literature and even traces the history of holocaust in general. The final chapter illustrates the various instances of violence and dehumanization in the novel which makes it a typical work on holocaust.
\end{abstract}

Keywords-Adorno, Germany, Holocaust Literature, World War Literature.

\section{INTRODUCTION}

Holocaust literature is a term used to refer to literary genre that includes a wide variety of texts, which exceed the classical boundaries of epic, poetry and drama. In other words it is a term used to refer to any literary work about the Holocaust. The concept was originally developed in America, initiated by the literary scholar Susan Cernyak-Spatz, who herself survived the Holocaust. Holocaust lasted from 1933-1945 in Germany.

Holocaust literature not only includes diaries and chronicles written throughout the war but also memoirs and reports written and recorded by first-hand witnesses. The genre also covers fictional adaptations such as novels, plays and poems, which address the Holocaust as a central topic. Holocaust works are usually not aesthetic but is factual and realistic with a serious theme. Even texts written by the 'non-affected' group have to be included in this genre. This literature often sheds light on the unseen facts and horrors of Holocaust and the brutality with which people were treated.Famous Holocaust works include Night by Elie Wiesel, The Diary of a Young Girl by Anne Frank, Schindler's List by Thomas Keneally, The Book Thief by Markus Zusak etc.
The Boy in the Striped Pyjamas is a 2006 Holocaust novel. It is penned by John Boyne. The novel has sold more than nine million copies worldwide. It was the best-selling book of the year in Spain in 2007 and 2008 and has also reached number one on the New York Times bestseller list. The book, later in 2008, was adapted into a film of the same name. The book was first published on $5^{\text {th }}$ January 2006 by David Fickling Books.

John Boyne was born in Dublin, Ireland, in 1971 and studied English literature at Trinity College, Dublin, and creative writing at the University of East Anglia, Norwich, where he was awarded the Curtis Brown prize.

He has published ten novels for adults and five for younger readers including The Boy in the Striped Pyjamas which became a bestseller. His other famous works include Stay Where You Are and Then Leave, A History of Loneliness, The Absolutist, The Boy at the Top of the Mountains etc. He is also the author of the short story collection Beneath the Earth. He was awarded the Hennessy Literary 'Hall of Fame' Award for his body of work in 2012. He has won three Irish Book Awards for Children's Book of the Year, People's Choice Book of the Year and Short Story of the Year. $\mathrm{He}$ has also won a number of international literary 
awards including the Que Leer Award for the Novel of the Year in Spain and the Gustav Heinemann Peace Prize in Germany. His novels are published in fifty one different languages.

The book is a fictional tale about the friendship of the unlikeliest of friends, Bruno, a nine year old son of a Nazi commandant and Shmuel, a Jewish inmate of the concentration camp at Auschwitz who is of the same age as Bruno. Their innocence and unawareness of the 'Final Solution' and the Holocaust is very striking in this poignant story.

Bruno and his family are forced to move from their beautiful and luxurious house in Berlin to the less appealing home at "Out-With" (24) as a result of Bruno's father's promotion. He is oblivious to the ongoing war in Europe and their role in it. All he knows is that he has to leave his friends, school, house and neighbourhood and move to the new house where he is very lonely and got no friends to play with. His father, a strict man tells him that this would be their new home for the "foreseeable future" (48). Bruno is not happy here. He is bored and lonely and goes off to explore the woods. Though he had seen the fence from this window he thought it was some kind of a 'farm' and that the fence was built to keep animals from going astray. While he is exploring he discovers Shmuel, a boy like him but much sadder and smaller. Bruno and Shmuel are both happy as they both didn't have friends where they were at and were very happy in each other's company. Shmuel reveals to Bruno about his life before coming to the camp and how life for him and people like him has been hard ever since then. Bruno slowly starts to see the ugly truth and realizes that all that he has believed or was trained to believe were nothing but lies. His friendship with Shmuel takes him from innocence to revelation. He is kind to Shmuel and develops a close fondness to his "best friend for life" (213). He feels guilty for not standing up for Shmuel when Lieutenant Kotler called him a thief and a liar and he apologizes. He brings Shmuel food often.

One day Shmuel tells Bruno that he is unable to find his father and seeks his help. Bruno agrees to help his friend. Shmuel brings Bruno the striped pyjamas, shirt and a hat that the inmates of the camp wear so that he would easily blend in with the people on the other side of the fence. Bruno sneaks into the other side of the fence and as they begin their search the truth dawns upon Bruno that the camp is not anything like he had imagined it to be. He could see sad faces everywhere. Soon a group of soldiers arrive and force them and a group of men to 'march' into a chamber in which they are gassed to death.

The Boy in the Striped Pyjamas is about childhood innocence in a time of war, horrors of the Holocaust, the common desire for friendship and the fence- both figurative and literal- that we must navigate and choose whether or not to break down. It also deals with the impact and influence of war on people especially innocent children and the futility of war.Bruno is characterized by an endearing childhood innocence which becomes poignant when he meets Shmuel. He remains unaffected by the war and unmoved by the Nazi beliefs and propaganda which he confronts daily. Bruno represents man's capacity for kindness and compassion.

Bruno and Shmuel seem to lead parallel yet mutually exclusive lives. They share common interests, birthday, and a similar perspective on life. Their friendship defies possibility. Shmuel and Bruno demonstrate how resistant and resilient children can be and how important kindness and compassion are in a world where people were being told what to think, who to hate and what is acceptable.

The first chapter deals with a general overview of what Holocaust is, what a Holocaust literature is, how it varies from other types of literature, different types and features of Holocaust literature and its characteristics. The second chapter deals with the argument that The Boy in the Striped Pyjamas is a Holocaust novel and tries to prove this by using instances and references from the primary text that is indicative of the prejudice the Germans had towards the Jews.

\section{A GENERAL OVERVIEW OF HOLOCAUST LITERATURE}

The Holocaust or the Shoah was the statesponsored, bureaucratic, systematic murder and torture of six million European Jews by Adolf Hitler's Nazi Germany and by the World War II collaborators with the Nazis. The term 'Holocaust' goes back to its Greek origin which means to 'sacrifice by fire'. The Nazis came to power in Germany in January 1933. They believed that that Germans were 'racially superior' and that the Jews deemed inferior were an alien threat to the so-called German racial community. Two-thirds of the nine million Jews who had resided in Europe and 1.5 million children were the victims of the Holocaust.

During the era of the Holocaust, other groups were also targeted by the German authorities due to their 
'racial inferiority': Roma (gypsies), the disabled and some of the Slavic people (Poles, Russians, and others). Other groups were persecuted on ideological, political and behavioural grounds. Among them were Socialists, Communalists, Jehovah's witnesses, homosexuals and mentally or physically disabled patients.

In 1933, the Jewish population of Europe stood at over nine million. Most of the European Jews lived in countries that Nazi Germany could easily occupy or influence during World War II. The Germans and their collaborators killed nearly two out of every three European Jews as part of the 'Final Solution'- the Nazi policy to murder the Jews of Europe by 1945.

There is a wide range of ways in which people have represented the Holocaust in popular culture. It may be through literature, music, theatre, visual arts, dance and other forms of representation. Literature in particular has an inherent value. It has an ability to transport readers to different times, distant places, and unique circumstances. Through literature, readers can also make personal connections and relate with the characters, may it be real or fictional.

Holocaust literature sheds light on the voices of victims. It can be seen as a survivor's testimony that includes accounts of their resistance and may also include stories of their rescue and heroism. It also deals with the German experience and the aftermath of the execution of the victims.

Holocaust Literature may be in the form of autobiography, memoir, poetry or diary or can even be fictional in nature. It could be the depiction of the events of the Holocaust through fiction, drama, and poetry. Some literature about the Holocaust is written as historical fiction. Such writings closely follow actual events, adding only imaginary dialogues that are consistent with those events. Other writings are much more removed from the actual course of events, and use allegory and other ahistorical literary devices in order to convey its point across efficiently to the readers. The Holocaust has influenced nearly any Jewish writer since and many nonJews.

Since the genre emerged, the defining stance of Holocaust literature was to see if its verisimilitude or truthvalue far outweighed its literary merit. The memoir which is a first person account has long been considered the apotheosis of Holocaust writings. "Holocaust literature comprises all forms of writing, both documentary and discursive, and in any language, that have shaped the public memory of the Holocaust and been shaped by it”(Roskies2).
To view Holocaust literature through the lens of genre is nothing but a dry, academic exercise. Diaries are universally acknowledged to be the most important source of wartime experience just like memoirs. By reading them in chronological order, we discover a specific type of diary that came into existence when the confinement and enslavement of Jews gave way to mass extermination. By examining the corpus of wartime writings produced outside the war zone, we discover how literature was used to mobilize the public and then provided them with the means for mourning. Reportage was only seen as second in importance to the diary inside the war zone.

The multilingual scope of Holocaust literature makes maximal demands of its readers, none of them who could possibly read the entire corpus of the original. Holocaust literature had its origin and developed in the habitat of public memory. Yet this did not come about everywhere at the same time. The growing public awareness of the Holocaust happened at the intersection of the private and public spheres. The real and the proxy witnesses began to write and publish, discovering new means of artistic expression and communication. Holocaust literature unfolds both backward and forward. Backward as previously unknown works are published and translated and they are later simply forgotten. Forward in the sense that new works of ever greater simplicity come into being.

Holocaust memory unfolded in fits and starts because much of its narrative violates the expectations of a specific public. Fierce controversies over a Holocaust novel, a play, even a poem, tend to happen in nations that look to literature for self-definition: Russia, Poland, France, Italy, Palestine and Yiddish land. In these places, the public looks at high culture and literary expression to bridge the gap between generations. In short we can always note that the course of Holocaust memory never actually had a smooth track.

Holocaust literature can portray the voices of the victims. Literature belonging to this category focuses on the importance of personal writing as a means of understanding the Holocaust. These diaries, stories and poems also serve as a medium to humanize the vast numbers of Holocaust victims by introducing readers to individuals with understandable dreams and passions which were mercilessly thwarted by the Nazis and also the agonies they faced. It can be a survivor testimony literature. The poignant testimony of Holocaust survivors reaffirms the will to live and to retain human dignity in the face of terrible adversities and hardships. These biographies and memoirs can further help to personalize historical events and to establish real faces in the 
overwhelming sea of facts and statistics. It shows us the real face of the war and the reality behind the 'fences' unlike records noted by the media or the Germans themselves. These testimonies usually talk about first-hand experience of the war and the atrocities the Jews had to face.

Holocaust literature can also be seen as an account of resistance. There are thousands of unsung heroes of the Holocaust, both Jewish and non-Jewish, who resisted the Nazis in ways big and small. They stood up to defend themselves and their fellow beings. These remarkable stories of defiance and resistance counter the myth that the Nazi victims passively submitted and succumbed to the Germans and to their fate.

Further, Holocaust literature can also include stories of rescue and heroism. It is imperative and necessary that the world recognize and remember the actions of the so called 'Righteous Gentiles' also known as 'Righteous Among the Nations', those relatively few individuals who took definite steps and frequently risked their own lives to save their fellow human beings. Many of those who deserve praise and honour are no longer alive to tell the stories. The horrors of the Holocaust are so numerous and so overwhelming that the occasional heroic act often goes unnoticed or is often forgotten. Researchers did not even begin to seriously study the many instances of rescue during the Holocaust until decades after the end of World War II.

Holocaust Literature can portray the German experience. If the goal of Holocaust literature is to prevent the recurrence of such tragedy, then we must carefully and closely examine the participants and the circumstances that eventually permitted the rise to Nazism. Literature in this category focuses on life in Germany during the rise and rule of the 'Third Reich' i.e., Nazi Germany.

The major portion of Holocaust study focuses on the victims and the survivors of Nazi persecution. Recently, however, much attention has been given to the psychological motives of Hitler and his followers. Researchers also examine the cultural climate, the specific personalities and the precise historical elements that came into play during Hitler's rise to power.

The purpose of this examination is not to glorify the regime that brought such horror to the world, nor to assign blame to the German people, but rather to uncover and learn from the intolerance and hatred that led to attempted eradication of an entire race from that face of the earth that was solely based on racial prejudice. Each of the issues, problems and dilemmas of the German Third Reich has parallels in the current events of the world. With careful and close analysis of the Holocaust, the world can better understand how to protect itself against tyranny. Some Holocaust literature can be seen as an aftermath of the war, as a response and reflection. These works deal with the moral lessons the world has learned after the very gory World War II.

One of the main problems that people want to write about the Holocaust is the horrifying nature of the event. The extremeness of the Holocaust is considered to be 'unrepresentable'. Despite this 'unrepresentability', much of our knowledge about the Holocaust has reached us through several mediums like for example through movies, theatres, documentaries, media like radio, newspaper etc. and through literature. One of the most important medium through which Holocaust can be depicted is literature.

In 1949, Theodore Adorno stated that to write a poem after Auschwitz is barbaric. He claims that using the Holocaust to create an aesthetic representation can be seen as a form of victim abuse. Poetry and literature in general belong under the broad classification of 'works of art' and this pleasurable principle contrasts strongly with the horrific and gory nature of Holocaust itself. In his essay, "Commitment", Adorno mentions the fact that the suffering of all Holocaust victims needs to be remembered and that suffering also demands the continued existence of the very art it forbids.

A written account of someone's experience can never convey the harsh reality of the original experience even though authors try their best to represent it through their works. There are many different opinions on whether or not the Holocaust should be dealt with using literature as the medium. One reason that seems to reappear regularly is the fact that the events are simply too horrifying in nature.

A part of the Holocaust survivors wants to write about the event in order to find some sort of closure for themselves and to vent out their personal emotions and frustrations associated with the Holocaust. Primo Levi divides the group of Holocaust survivors into two main categories i.e., "those who remain silent and those who speak" (121).

Because of the traumatizing nature of the Holocaust, people have often preferred to repress their memories. Nevertheless, their silent memories did not fade overtime. Writing down the experiences of the past can be perceived as a part of a therapeutic process. Within the process of working through the traumatic past, the act of testifying should be perceived as a key element.

Many Holocaust survivors seemed to live in the past. This proves that detachment from the cruel facts is almost impossible. The past seems to haunt them even 
though they live in the modern world far removed from the scene of the Holocaust. The first generations of the war were not the only ones who felt an urge to talk about the past. The members of the second and the third generations also search for new ways to deal with the Holocaust in modern society as they have to deal with this moral and psychological burden.

Holocaust literature has often been attacked by Holocaust deniers. This form of literature does not serve as a tool to undermine the Holocaust. All the authors intend to do is to make sure that people know about the events of the past and are fully aware of it through their works which serve as veritable sources. Hence, authors do play a very important role in the right representation of events and have a great responsibility in representing the Holocaust.

Literature has different genres like autobiographies, fiction, non-fiction, poetry and so on. No genre is considered the best to talk about the Holocaust. Some argue that testimonies would be the best sources about the Holocaust as they consistthe stories of real individuals who have suffered. Primo Levi thinks that this genre is insufficient as a testimony can never fully express the real experiences of the victims. "We, the survivors are not true witnesses.. . we are those who by their prevarications or abilities or good luck did not touch the bottom. Those who did so, those who saw the Gorgon have not returned to tell about it" (63-64).

Here we can see that Levi feels the testimonies are incomplete as they do not deal with the real experiences. For example no man detached from the war scene can talk about the experiences in the gas chambers as vividly and poignantly as a person who has managed to survive through this type of torture. He says that fiction helps to present a complete account of the Holocaust experience. "The survivors watch helplessly as the only real possessions are done away with: authentic experiences" (Kertesz269).

Nevertheless, fiction can be a useful medium which draws attention to the topic of Holocaust.The characteristics of Holocaust literature are as follows. It tells us about the Holocaust in general. It is more than mere historical facts but is an experience of individuals, victims, perpetrators, bystanders and heroes. It can be seen as fiction as well as non-fiction or at times can be a mixture of both. It is usually depressing as the goal of Holocaust literature is to make the readers aware of the strength of the survivors and their resilient spirit.

Readers are both fascinated by what happens due to suffering inhumanities and revulsion because of these events. Some readers will read more to expand their knowledge while still having a feeling of how horrible and gruesome these events are. All Holocaust literatures convey a common theme. If man becomes too intelligent and doesn't use his heart, he loses everything and will eventually perish.

Hitler's pursuit of his so called 'master race' was purely intellectual as he tried to exterminate an entire race after putting his own life at stake. He only looked denied on men for their strength and intelligence and never saw him as one with feelings and emotions and saw them as something expendable.

The Boy in the Striped Pyjamas can hence be clearly be seen as a Holocaust novel with its clear and vivid portrayal of racial prejudice and discrimination that the Germans had towards the Jews. An even more fascinating aspect of this novel is its representation of events through the innocent eyes of a nine year old who is unaware of the significance of war and though he is raised in a way so as to think of his country and race as being superior, he never actually practices it and unlike the rest of his folk, he actually cares about his fellow beings- be it a Jew or a German. More about the book and its Holocaust elements would be dealt with in detail in the next chapter.

\section{THE BOY IN THE STRIPED PYJAMAS AS A HOLOCAUST NOVEL}

The Boy in the Striped Pyjamas is a fictional tale of the improbable friendship between Bruno, the son of a Nazi Commandant and Shmuel, a Jewish concentration camp inmate. The novel written by John Boyne was published in 2006 and was adapted into a major motion picture in 2008. The book explores the evils of the Holocaust through the innocent eyes of a child. This novel contrasts the dichotomy of man's inhumanity to man with man's capacity to care and love. The author has said that according to him, the only way he could write about the Holocaust respectfully was through the eyes of a child. He demonstrates how Bruno and Shmuel maintain the innocence of their childhood in spite of the happenings around them.

Boyne agrees to the fact that the only people who can truly comprehend the horrors of the Holocaust are those who lived through it. This novel gives a voice to the victims of Holocaust, especially millions of innocent children who perished at the hands of the Nazis. The novel focuses on individual relationships and gives the readers intimate portrait of the two innocent boys seeking friendship rather than examining the big picture of Holocaust. The novel is more or less a fable.

In The Boy in the Striped Pyjamas, we can see characters with names Bruno, Gretel and Shmuel. Bruno 
means 'saint' or 'brown', Gretel means 'pearl' and Shmuel means 'his name is God'. From the selection of these different German and Jewish names we can see that they each have different meanings. The Germans sough power and strength during World War II and this is reflected in the very names they sought. Whereas the Jewish names always had something to do with God and religion which is what they are discriminated against. Their name meanings show their position in the war.

Bruno stands up for the universal notions of the good while the rest of the world is immersed in contingency. One of the horrors of the Holocaust is that everyone embraced a sense of contingency, of convenience. For the Nazis, it was convenient to target the Jewish people and those who were labelled as 'outsiders'.Contingency was also seen in the lack of solidarity and lack of community that resulted in Holocaust. People could not stand up for one another because of the fear of their own lives.

Bruno, unlike this, stood for universal qualities such as friendship, compassion and hope. This is emphasized when Bruno apologizes to Shmuel for not standing up for him in need. Bruno helps Shmuel to find his father and in the process gets killed. He agrees to help though something dangerous lurked beyond the fence and affirmed his friendship to Shmuel in the midst of certain death.

Usually we can see while studying Holocaust that people did what they had to in order to survive. Yet there are times when the individuals went beyond for the wellbeing of others. These were heroic people who represented universal values that bonded community and created solidarity in a world that did not validate it. Bruno was a hero in this manner.

Bruno is a naïve boy who doesn't know the seriousness of the events around him. The first time he saw Shmuel, he was envious thinking of the fact that he had a lot of friends to play with on the other side of the fence. Later, this conversation gradually gave way to their origin. Bruno was a German and was trained to think that they were superior. Shmuel was Polish.Bruno told that,"Poland. .. . That's not as good as Germany is it. . . Germany is the greatest of all countries. ... We're superior"(111).

The little boy had been trained to think that the Germans were superior. This is a result of 'Anti-Semitism' prevalent in the then German society i.e., hatred of and prejudice towards Jews. The Germans considered the Jews to be 'filthy', disgusting and not human. This is evident in Kotler's remark, "And afterwards when you return to the kitchen, make sure you wash your filthy hands before touching any of the food ..."(76).
The Nazis were against books that did not match Nazi views. They burned it publicly. In the novel, Bruno loves tales of adventure and exploration. He is discouraged by his private tutor, Herr Liszt who was very fond of "history and geography" (97). He told Bruno that books on art are useless and that he should study about things that matter in this world.

$\ldots$. study the things that I say are
important ... not story books. Not
books about things that never
happened. . . I am here to . . . get
your head out of your storybooks
and teach you more ... about where
you come from. . . About the great
wrongs that have been done to you.
(97-98)

The Hitler Youth was the only youth movement in power at that time in Germany. The boys were prepared for military service, and the girls for being mothers and housewives. This is evident in Kotler's appearance as noted by Bruno. Bruno describes Kotler as a young man of nineteen who looked like the "big boys at school" (72).

Schools were an important medium through which Nazi ideologies were imparted into the minds of children. Teachers taught students to love Hitler, to obey the Nazi regime, and to hate Jews. Herr Liszt is an example of the way teaching was focused on Nazi ideology. Hitler was known as Fuhrer, German for 'leader' and Germany was known as 'the Fatherland' or 'Vaterland'.

On September 1939, Germany invaded Poland, marking the beginning of World War II. German officials confiscated Jewish property, forced Jews to wear identifying armbands, and established ghettoes and forced labour camps. Shmuel talks about this experience as he narrates his story to Bruno. He tells him how he and his family came to be at Auschwitz.

And then one day things started to change. . . . I came home from school and my mother was making armbands for us ...(126)

Then one day the soldiers came with huge trucks. ... And everyone was told to leave the houses. . . . And the trucks took us to a train ... there was no air to breathe ... when the train stopped . . . we all had to walk here.(129-130)

Einsatzgruppen (mobile killing units) often with the support from local civilians and police followed the 
German army. They carried out mass shootings and massacre. From 1942-1945 while Nazi Germany was fighting on both the eastern and western fronts, they also pursued the 'Final Solution' of murdering all Jews in the world. Millions of Jews were butchered mercilessly. Many were gassed, shot, starved or died of diseases, such as typhus.

The Auschwitz-Birkenau concentration camp complex, where The Boy in the Striped Pyjamas is set, was one of many built by the Nazis. Bruno describes the camp which he first imagined to be a 'farm' and the people who lived on the other side of the fence.

There were small boys and big boys, fathers and grandfathers. Perhaps a few uncles too.... .

There was a huge wire fence. . . . The fence was very high. ... At the top of the fence enormous bales of barbed wire were tangled in spirals ... (30-31)

Bruno and his sister first thought that the camp was a farm and the fence was built to prevent the animals from going astray. Little did they know that they were people killed and tortured under their father's supervision.

Some stood perfectly still in groups, their hands by their sides. . . . As a soldier marched in front of them, his mouth opening and closing quickly as if he were shouting something at them. Some were ... pushing wheelbarrows from one side of the camp to the other. . . . a group of children huddled together, but then one of the soldiers lunged towards them. ... when they did the soldiers all started to laugh and applaud them.(36-37)

Bruno, being a German, and Shmuel, being a Jew, were supposed to be sworn enemies. Unlike their families and the society, they turned out to be best friends having no prejudices against each other. Bruno, at first, thought that he is superior as he is from Germany but hurting Shmuel saddened him. This shows how humane he was unlike his parents.

Even though they are not meant to be together due to their circumstances, fate brings them together. The fence which is a symbol of separation does not stand in the way of their friendship. A poignant scene is when they both are shut inside the gas chamber and Bruno seizes Shmuel's hand saying, "You're my best friend, Shmuel. . . . My best friend for life"(213).
The Germans showed a sense of superiority and held a strong sense of prejudice against the Jews. This is very evident in the way Lieutenant Kotler treats Pavel. Pavel is pushed around, tortured, harassed, abused and cursed by Kotler. "'Hey you . . . come over here, you-' . . . something about the harsh sound of it made Bruno look away and feel ashamed to be a part of this at all" (75).

Kotler was being very curt and saw Pavel as a mere slave - a puppet. This shows how the Germans demanded respect and obedience from the Jews.During dinner one day, Pavel lost his grip of the wine bottle and its contents fell directly onto Kotler's lap. This made him beat up Pavel mercilessly. "What happened was both unexpected and extremely unpleasant. Lieutenant Kotler grew very angry with Pavel and no one stepped in to stop him doing what he did next, even though none of them could watch. Even though it made Bruno run away and Gretel grow pale" (148-149).

The soldiers were treated with reverence. Bruno had thought that the world beyond the fence was a happy world with happy people.

As it turned out, all the things that he thought might be there - weren't. . . . there were crowds of people sitting together in groups, staring at the ground, looking horribly sad; they all had one thing in common: they were all terribly skinny and their eyes were sunken and they all had shaved heads. . . . he could see two different types of people: either happy, laughing, shouting soldiers in their uniforms or unhappy crying people in their striped pyjamas . . . (207208)

This shows the misconceptions of people about what really happens in the camp not realising the fact that it was a slaughterhouse. Many people who had respectable positions in the society were reduced to a mere speck of dirt owing to the fact that they were Jews. Pavel, once a doctor, is now a servant peeling vegetables for dinner. Pavel dressed Bruno's wounds and Bruno's mother didn't want their father to know about this. Bruno tells Shmuel about this. "If father had known that he had cleaned my knee when I hurt myself then there would have been trouble"(139).

This shows how much the Germans despised the Jews and coming in contact with them was looked upon with disgust. Even men who had prestigious professions became no one but mere servants acting on the commands of the German soldiers. Children from a very young age 
were trained to respect Hitler though they didn't understand the significance of the events around them, and didn't know who Hitler himself was. Bruno thought 'Heil Hitler' was a salutation denoting respect. "Heil Hitler, he said which, he presumed, was another way of saying, Well, goodbye for now, have a pleasant afternoon" (54).

Gretel, Bruno's elder sister was first obsessed with dolls, later towards the tragic conclusion of the story, Gretel's obsession switches from her doll collection to the war slowly. Gretel becomes a fervent believer in the Nazi ideal and adorns her bedroom with maps from her father which she used to track the wars. This practice of tracking the war's progress on maps becomes a substitute for her doll collection. This shows the impact of the war on innocent children like Gretel and how it transforms them.
Gretel's room had changed considerably. . . . there wasn't a single doll in sight. . . .Gretel had decided that she didn't like dolls anymore and put them all into four large bags and thrown them away. In their place she had hung up maps of Europe that father had given her and everyday she put little pins into them. . . . Bruno thought she might be going mad.(180)

Even though the Germans were hostile towards the Jews, there were a few who pitied the unfortunate Jews. This is striking in the way Bruno's grandmother reacts to her son's promotion. She says, "I wonder is this where I went wrong with you, Ralf?"(90).However his grandfather (Matthias) is very proud of his son, who to him was a patriot. He was very proud of his son who was a soldier and worked for the 'greater good' of his fatherland.

During World War II, many Jewish people were forced to live in ghettoes walled or fenced areas within a city. The most famous of these was the Warsaw Ghetto, where about 400,000 Jews were forced into an area of 1.3 square miles. The ghetto was enclosed by a wall that was over 10 feet high, topped with barbed wire, and closely guarded to prevent movement between the ghetto and the rest of Warsaw.

In the novel, however, Shmuel describes living in the ghetto in Cracow. "No, but then we were told we couldn't live in our house we had to move to a different part of Cracow, where the soldiers built a big wall and my mother and father and my brother and I all had to live in one room" (128). The Jews were not given a chance. They were forced to abandon everything they owned and follow the commands of the German soldiers. People who hid from them were either caught or brutally killed.
To facilitate the Final Solution, the Nazis established killing centres in Poland, the country with the largest Jewish population. The killing centres were designed for efficient mass murder. They constructed gas chambers (rooms that were filled with poisonous gas to kill those inside) for easy killing and to make the process more impersonal for the perpetrators. At Auschwitz camp there were four gas chambers and up to 6,000 Jews were gassed there each day.

Bruno, having crossed the fence to help Shmuel's father, discovered the world beyond the fence was a very sad and gloomy one. He was sad that he couldn't find any "evidence" (209) and was about to head back home when a group of soldiers surrounded the area where they were standing. Shmuel said that,"they make people go on marches. . . I I never see the people after they've gone on a march"(210-211).

They found themselves in a room (the gas chamber) ". . . from all the marches who had filled the room, as the door at the front was suddenly closed and a loud metallic sound rang through from the outside"(213). Even though Bruno was compassionate towards Jews, Gretel, unlike him was not so. She believed in the same ideologies like her father. This came as a revelation to the naïve boy.

\section{... the fence isn't there to stop us from going there. It's to stop them from coming over here. . . . Because they have to be kept together. . . . But with their own kind too. . . . With the other Jews. . . . They can't mix with us. ... All the people over that side of the fence are Jews. (182)}

Bruno's innocent mind, unable to comprehend the depth of what she uttered, asked why it was so. ". . . It's us who don't like them"(183) was all she replied. This shows that unlike Bruno she does not sympathise with the Jews.

This shows how the notion of German superiority and the inferiority of the Jews that hung in the airchanged many, including the viewpoints of naïve young children and how Jews were trivialized. The Jews were merely seen as expendable objects who were a threat to the Germans which had to be eliminated once and for all.

This chapter gives us a glimpse of the lives of two nine year old boys during Holocaust and how this influenced their lives and resulted in their tragic ends. It deals with many instances from the book where the Jews are oppressed and tortured and how the German notion of superiority is imposed upon the minds of young children. It also deals with how the Holocaust played an important role in shaping the lives of people. 


\section{CONCLUSION}

Holocaust literature can hence be summed up as any work composed that deals with the Holocaust of the twentieth century Germany under the dictatorship of Adolf Hitler. These works can be autobiographical, written in the form of a diary or a memoir, which deals with the experiences and the tragic plight of the first hand witnesses of the Holocaust. It can also be biographical written by people who were far removed from the scène of war and looked at it from the outside. Totally detached and unaffected but who empathized with the victims. It can also be fictional that includes imaginary characters, places, events and incidents but focusing on the Holocaust as the main subject and its influences on the characters. These writings do not usually serve an aesthetic purpose and do not entertain. On the other hand, they are factual. They usually deal with the experiences of the victims and is more of a survivor testimony that talks about their accounts of resistance and heroic rescues. Some Holocaust writings also deal with the aftermath of the war and how to prevent such wars in the future.

Set during World War II, The Boy in the Striped Pyjamaswritten by John Boyne is a fictional tale about the Holocaust seen through the innocent eyes of a nine year old naïve boy named Bruno. His father is the Nazi Commandant and their family is forced to move from their house at Berlin to their new home at 'Out-With' as a part of his father's promotion. Bruno dislikes his new home and is bored and lonely. One day as he decides to go 'exploring', he comes across Shmuel, a nine year old Jewish boy who lives on the other side a huge fence and their friendship changes their lives forever.

This book can be viewed as a fine example of a Holocaust literature. It deals with the influence of the Holocaust on young and innocent minds of the children and how it transforms them. It also deals with the way the Jews were mistreated and were put in concentration camps, surrounded by huge fences devoid of any correspondence with the outside world, and were made to work day and night and were brutally tortured. There are many instances in the book that display German superiority and their racial prejudice towards the Jews. This is very evident in the way Pavel, a Jew, is treated by Lieutenant Kotler. It also sheds light on how people's perceptions and their individual selfchange as a result of war.The education system is also affected by the war. Bruno however remains unaffected by the evils prevalent in the society and retains his humane, innocent self.

Thus it is possible to view The Boy in the Striped Pyjamas as a Holocaust novel as it deals with the tragic plight of the Jews and the Auschwitz camp inmates. The novel clearly draws a perfect picture of the Holocaust through the innocent mind of a young boy and is successful in painting a vivid and poignant picture of the Holocaust.

\section{REFERENCES}

[1] Abrams, M. H. A Glossary of Literary Terms. Cengage Learning, 2014.

[2] Adorno, Theodor. "Commitment."Notes on Literature. Columbia University Press, 1991, pp. 76-94.

[3] Barry, Peter. Beginning Theory. Oxford UP, 2013.

[4] Boyne, John. "Biography."John Boyne, johnboyne.com/about/. Accessed5 Mar. 2017.

[5] "Characteristics of Holocaust Literature." Word Press, February 2016, sanduskygrade9.files.wordpress.com/2016/02/characteristi cs-of-holocaust-literature-notes.doc. Accessed2 Mar. 2017.

[6] "Introduction to the Holocaust. "United States Holocaust Memorial Museum, www.ushmm.org $/$ wlc/mobile/en/article.php?Moduleld=10 005143. Accessed 3 Mar. 2017.

[7] “John Boyne's The Boy in the Striped Pyjamas: Holocaust from a Child's Perspective Essay." Study Moose,January 2017, studymoose.com/john-boynes-the-boy-in-thestriped-pyjamas-holocaust-from-a-childs-perspectiveessay\#. Accessed3 Mar. 2017.

[8] Kaiser, Menachem. "The Holocaust's Uneasy Relationship with Literature." The Atlantic, December 2010, www.google.co.in/amp/s/www.theatlantic.com/amp/article /67998. Accessed6 Mar. 2017.

[9] Kertesz, Imre. "Who Owns Auschwitz?" Translated by John McKay, Yale Journal of Criticism, www.academia.edu/7423276/Imre_Kertesz_Who_Owns Auschwitz_Translated_by_John_MacKay. Accessed 3 Mar. 2017.

[10] Levi, Primo. The Drowned and the Saved.Summit Books, 1988.

[11] "Literatureon the Holocaust." YadVashem, www.yadvashem.org/odot_pdf/Microsoft\%20Word\%20\%206409.pdf. Accessed 7 Mar. 2017.

[12] Richardson, Anna. "The Ethnical Limitations of Holocaust Literary Representation." Borders and Boundaries,www.gla.ac.uk/media/media_41171_en.pdf. Accessed 3 Mar. 2017.

[13] Roskies, David G. and Naomi Diamant.Holocaust Literature: A History andGuide. Brandeis UP, 2012.

[14] "The Boy in the Striped Pyjamas."Enotes,www.enotes.com/topics/the-boy-in-thestriped-pyjamas. Accessed 2 Mar. 2017.

[15] "The Boy in Striped Pyjamas." WordPress.com., 27 July 2012, tbisp.wordpress.com. Accessed 5 Mar. 2017.

[16] "The Boy in the Striped Pyjamas."IMDB, m.imdb.com/title/tt0914798/plotsummary. Accessed 4 Mar. 2017. 
[17] "The Boy in the Striped Pyjamas Resource Pack." The Boy in the Striped Pyjamas, www.theboyinthestripedpyjamas.com/downloads/BISPResource-Pack.pdf. Accessed 5 Mar. 2017.

[18] “The Holocaust."History, www.history.com/topics/worldwar-ii/the-holocaust. Accessed 6 Mar. 2017.

[19] Vleeschouwer-Potvin, Janna. "HolocaustLiterature for Children and Adolescents."Ghent University, August 2010,lib.ugent.be/fulltxt/RUG01/001/457/818/RUG01001457818_2011_0001_AC.pdf. Accessed 7 Mar. 2017. 